\title{
Life history of Onisimus caricus (Amphipoda: Lysianassoidea) in a high Arctic fjord
}

\author{
Henrik Nygård ${ }^{1,2, *}$, Mikko Vihtakari ${ }^{1,3}$, Jørgen Berge ${ }^{1}$ \\ ${ }^{1}$ The University Centre in Svalbard, PB 156, 9171 Longyearbyen, Norway \\ ${ }^{2}$ Norwegian College of Fishery Science, University of Tromsø, 9037 Tromsø, Norway \\ ${ }^{3}$ Department of Biological and Environmental Science, University of Jyväskylä, 40014 Jyväskylä, Finland
}

\begin{abstract}
Knowing the life history of individual species is essential for understanding the functionality of the ecosystems in which they occur. In this study we present the life-history traits of the benthic scavenging amphipod Onisimus caricus Hansen, 1887, observed in Adventfjorden $\left(78^{\circ} 14^{\prime} \mathrm{N}\right.$, $15^{\circ} 37^{\prime}$ E) in Svalbard. The sampling campaign was carried out on a monthly basis throughout a full year (September 2006 to August 2007) using baited traps. The results show that O. caricus is a typical adverse-selective ( $A$-selective) species with a 5 yr life cycle. During the first 2 yr $O$. caricus individuals do not appear to develop any visible external sexual characters, but these are detectable in $3 \mathrm{yr}$ old immature specimens. Males start to mature in the fourth year and may be iteroparous, depending on whether they mature before the mating season in the fourth year and survive to the mating season in the fifth year. Females are semelparous, maturing in their fifth year. Reproduction takes place in January to February, and juveniles are released in July to August. Unlike many other Arctic scavenging amphipods that are dependant upon the spring bloom for releasing the brood, the release of juveniles is synchronized with peak mortality of zooplankton late in the melting season, which results in a large quantity of dead organic material on which juveniles can feed.
\end{abstract}

KEY WORDS: Life cycle $\cdot$ Reproduction $\cdot$ Timing $\cdot$ Scavenger $\cdot$ Onisimus caricus $\cdot$ Arctic $\cdot$ Svalbard

\section{INTRODUCTION}

Amphipods are one of the most diverse marine macrofaunal taxa in Svalbard waters (Palerud et al. 2004). They inhabit a variety of habitats from the intertidal zone to the deep sea, the pelagic waters, and seaice, where they are important links transferring energy from primary and secondary production to higher trophic levels (Lønne \& Gulliksen 1989, Lønne \& Gabrielsen 1992, Węsławski et al. 1994, Steen et al. 2007). Scavenging amphipods also play an important role in recycling dead organic material back to the food chain in deep-sea habitats and at high latitudes (Ingram \& Hessler 1983, Slattery \& Oliver 1986, De Broyer et al. 2004, Premke 2006).

The motile scavenging fauna of Arctic fjords mainly consists of lysianassoid amphipods, and the most common species in Svalbard waters belong to the genera
Anonyx and Onisimus (Legeżyńska et al. 2000). Cooccurrence of these 2 genera is common in the Svalbard fjords, but in this environment they tend to be separated by depth (Legeżyńska et al. 2000), and exploit different food resources (Legeżyńska 2008). Onisimus caricus lives on soft bottoms in glacial bays and fjords in Svalbard. It occurs at depths $>5 \mathrm{~m}$ and is mainly found at 30 to $60 \mathrm{~m}$ depth (Legeżyńska et al. 2000). The diet of $O$. caricus varies with season. Previous studies have indicated that it feeds on dead zooplankton during the melting season, and uses other carrion the rest of the year (Zajączkowski \& Legeżyńska 2001). The frequent occurrence of sediment grains in dissected guts suggests scavenging feeding behavior on the bottom rather than active pelagic predatory behavior (Zajączkowski \& Legeżyńska 2001, Legeżyńska 2008). Little is known about the life cycle of this species. Some reproduction parameters for $O$. caricus have been reported by Węs- 


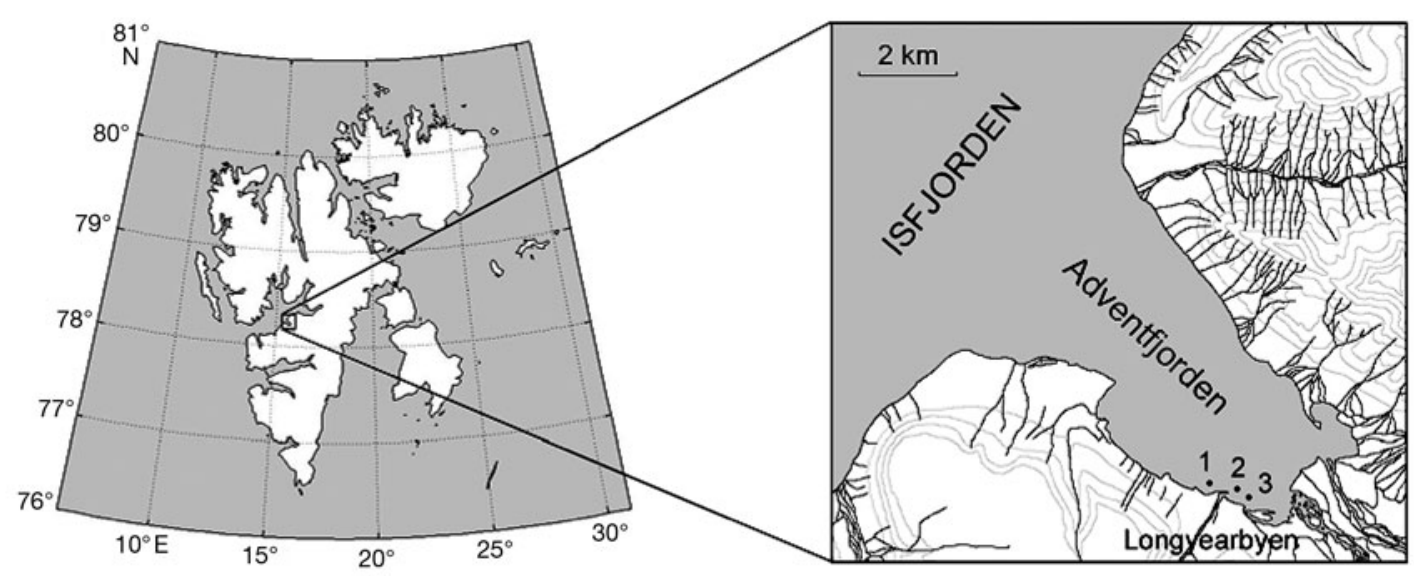

Fig. 1. Svalbard and location of Adventfjorden. Number: locations of the 3 trap transects

ławski \& Legeżyńska (2002), but their description of the life cycle was based on a small-sized sample.

A species' life-history traits are the basis for its biology and ecology, and many amphipods have been studied (reviewed by Wildish 1982, Sainte-Marie 1991). Among these are also Arctic amphipods (Boudrias \& Carey 1988, Sainte-Marie et al. 1990, Poltermann et al. 2000, Węsławski et al. 2000, Beuchel \& Lønne 2002, Węsławski \& Legeżyńska 2002, Arndt \& Beuchel 2006). In general, Arctic amphipods have a single brood per year, which is released in synchrony with optimal conditions, resulting in distinct cohorts, which can be used for life cycle analyses.

Our main objectives were to describe the life cycle and key reproductive parameters of Onisimus caricus, and to relate these characteristics to seasonal changes in food availability and other environmental conditions. Furthermore, we aimed to test the hypothesis that $O$. caricus has a 2 yr life cycle (Węsławski \& Legeżyńska 2002).

\section{MATERIALS AND METHODS}

Sampling was carried out with baited traps in Adventfjorden, western Spitsbergen (Fig. 1). Adventfjorden is a glacial bay, supplied with fresh melt water from rivers during late May to September (Węsławski et al. 1999, Zajączkowski 2008). During the study period, the bottom water temperature varied from $4.8^{\circ} \mathrm{C}$ in August to $-1.2^{\circ} \mathrm{C}$ in April. The bottom water salinity varied between 32.5 in July and 35.5 in March, whereas the surface water varied between 4.7 in August and 34.9 in March (M. Zajączkowski unpubl. data).

Samples were taken 10 times, at approximately monthly intervals between September 2006 and August 2007 (Table 1). Because of drifting ice in April and May 2007, the sampling largely failed, since the ice moved the transects. For sampling, baited traps consisting of plastic pipe $(20 \mathrm{~cm}$ long, $10 \mathrm{~cm}$ in diameter) with a funnel attached to one end and a removable net (mesh size: $1 \mathrm{~mm}$ ) on the other end were used (see Arndt et al. in press). The bait was raw chicken meat packed in fine-mesh bags to prevent the amphipods from eating it. Sampling was conducted with $24 \mathrm{~h}$ deployments on 3 transects with 5 traps each (Fig. 1). All transects started at 1 to $2 \mathrm{~m}$ depth, close to shore, and extended into the fjord so that the last trap was $\sim 150 \mathrm{~m}$ from shore at 20 to $30 \mathrm{~m}$ depth.

Onisimus caricus (Fig. 2) were identified and sexed under a stereomicroscope (16× magnification), and the length of the first pereonal segment $\left(L_{\mathrm{s}}\right)$ was measured with an accuracy of $0.06 \mathrm{~mm}$. Because of the curvature of the amphipods the total length was estimated following Arndt \& Beuchel (2006). The total length $\left(L_{\mathrm{t}}\right.$ from the front of the head to the tip of the telson) and $L_{\mathrm{s}}$ were measured by image analysis using the software ImageJ (http://rsb.info.nih.gov/ij/) on 129 randomly selected

Table 1. Sampling dates, transects, number of baited traps used, total catch of Onisimus caricus and size of subsamples. April and May 2007 were disturbed by drifting ice. (-) depth not recorded

\begin{tabular}{|lccrrc|}
\hline Date & Transect & $\begin{array}{c}\text { Depth } \\
\text { range (m) }\end{array}$ & Traps & $\begin{array}{r}\text { Total } \\
\text { catch }\end{array}$ & $\begin{array}{c}\text { Subsample } \\
\text { size }\end{array}$ \\
\hline 2006 & & & & & \\
Sep 29 & 1,2 & - & 10 & 325 & 278 \\
Oct 19 & $1,2,3$ & $2-18$ & 30 & 3131 & 1005 \\
Nov 7 & $1,2,3$ & $2-24$ & 30 & 6139 & 1201 \\
Dec 7 & $1,2,3$ & $2-31$ & 15 & 1721 & 950 \\
2007 & & & & & \\
Feb 8 & $1,2,3$ & $1-34$ & 15 & 1035 & 582 \\
Mar 21 & $1,2,3$ & - & 15 & 638 & 465 \\
Apr 19 & $1,2,3$ & $2-33$ & 15 & 974 & 264 \\
May 23 & $1,2,3$ & $1-28$ & 15 & 79 & 71 \\
Jun 20 & $1,2,3$ & $1-33$ & 15 & 2469 & 875 \\
Aug 15 & $1,2,3$ & - & 15 & 496 & 492 \\
\hline
\end{tabular}




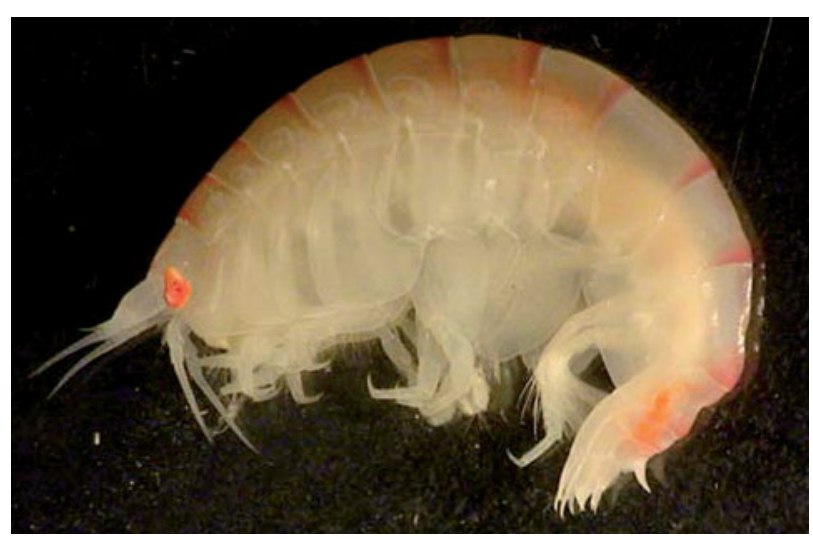

Fig. 2. Onisimus caricus. Length of specimen: $23 \mathrm{~mm}$

individuals. The allometric relationship between $L_{\mathrm{s}}$ and $L_{\mathrm{t}}$ was plotted and verified through linear regression analyses (ANOVA: $F=3226, \mathrm{df}=127, \mathrm{p}<0.0001$ ), and the formula for the linear regression: $L_{\mathrm{t}}=17.3348 \times L_{\mathrm{s}}-$ $0.5443,\left(R^{2}=0.962\right)$, was used to estimate $L_{\mathrm{t}}(95 \%$ confidence for the estimate $\pm 1.29 \mathrm{~mm}$ ). Since the accuracy of the $L_{\mathrm{s}}$ measurement was $0.06 \mathrm{~mm}, L_{\mathrm{t}}$ could theoretically be estimated with an accuracy of $1 \mathrm{~mm}( \pm 0.5 \mathrm{~mm})$. The length of the amphipods hereafter refers to the estimated total length. Large samples (traps containing $>100$ O. caricus) were randomly subsampled so that $\sim 100$ ind. were sexed and measured. If many traps were empty or contained few amphipods, the subsamples from large samples were increased, aiming at having 300 to 400 measured $O$. caricus on each sampling date. In order to identify the gender of the specimens, the presence of genital papillae was used for determining males, whereas the presence of oostegites was used for identifying females. Males were considered mature when the second antenna was elongated, while long oostegites with setae were used to define the maturity of females, following Boudrias \& Carey (1988). In addition, a subsample of females was used to classify the development stages of the oostegites as follows: tiny (barely visible nodes), small (clearly visible, but small nodes), intermediate (elongated), long (long oostegites, but no setae), and adult (oostegites with setae).

The length of the amphipods was plotted in genderspecific histograms, with $1 \mathrm{~mm}$ length classes for each month. Kernel density estimates (bandwidth selected as default in the $\mathrm{R}$ density function) were used to smooth the data. Using mixture distribution analyses (MacDonald \& Pitcher 1979, MacDonald \& Green 1988) and the 'mixdist' package in the R-statistical environment (www.r-project.org), cohorts of the genderspecific distributions were modeled, following the histograms. The fitting of the model was run with 10 expectation-maximization (EM) steps (explained in detail in Dempster et al. 1977). To optimize the good- ness-of-fit (chi-squared ANOVA), normal or lognormal distributions and best fitting constraints for SDs were used, following the instructions of $\mathrm{Du}$ (2002).

Mean lengths of the cohorts obtained by the mixture distribution analysis were used to model the Gompertz growth curve for Onisimus caricus. The mean diameter of eggs was used as the 0 age point. The Gompertz growth model was calculated using the formula: $L_{\mathrm{t}}(a)=$ $L_{\mathrm{t} l i m} \mathrm{e}^{k \mathrm{e}^{-b a}}$, where $L_{\mathrm{t}}(a)$ is the estimated total length of an amphipod at age $a, L_{\mathrm{t}} \lim$ is the asymptotic body length, $k$ is the growth constant, and $b$ is the theoretical age when $L_{\mathrm{t}}(a)$ is 0 . Because the largest $O$. caricus found during the study was $30 \mathrm{~mm}, L_{\mathrm{t}} \lim$ was set to 30 . All cohorts that had proportions $<0.3$ were excluded from the model. The parameters for the model were iterated using the nonlinear least-squares method and the 'port' algorithm in R. Residuals of the fitted parameters followed a $t$-distribution with $\mathrm{p}<0.001$. The model has previously been used for $O$. nanseni and $O$. glacialis (Arndt \& Beuchel 2006), which enabled us to compare growth parameters among congeneric species (Vader et al. 2005).

\section{RESULTS}

\section{Monthly samples and cohorts}

In total 17007 Onisimus caricus individuals were caught during the study, of which 6183 were measured and included in the life cycle analysis. By plotting these in gender-specific length-frequency histograms, certain cohorts could be identified throughout the year with the help of kernel density distribution and mixture distribution analyses. The mean length of the cohorts was estimated with the mixture distribution analysis (Table 2). Juveniles were abundant throughout the year and seemed to have 3 cohorts (Fig. 3). Juveniles dominated the samples in all months except February and March. The smallest juveniles $(5 \mathrm{~mm})$ caught were found in February.

Males appeared to have 2 immature cohorts most of the year (Fig. 4). The first cohort of immature males overlapped with the third cohort of juveniles. In October and December, 2 cohorts of mature males were found, whereas few mature males were caught in April and May. The abundance of males in the samples seemed to increase towards the winter, and, proportionally, most mature males were found in February and March. Mature males were observed throughout the year.

Females generally had 2 cohorts of immature and 1 cohort with mature individuals (Fig. 5). There seemed to be an overlap between the third cohort of juveniles and the first cohort of immature females. The abun- 
Table 2. Onisimus caricus. Mean lengths of cohorts as an output from the mixture distribution analysis. $\pi$ : proportion; $\mu$ : mean length $\pm \mathrm{SE}$; $\sigma$ : standard deviation of the modeled distribution. Mixture method: constraints used in analysis (see Du 2002 for details). CCV: constant coefficient of variation; NONE: no constraints used; SEQ: equal variation. Distributions (Dist) were normal (Norm) or log-normal (Lnorm)

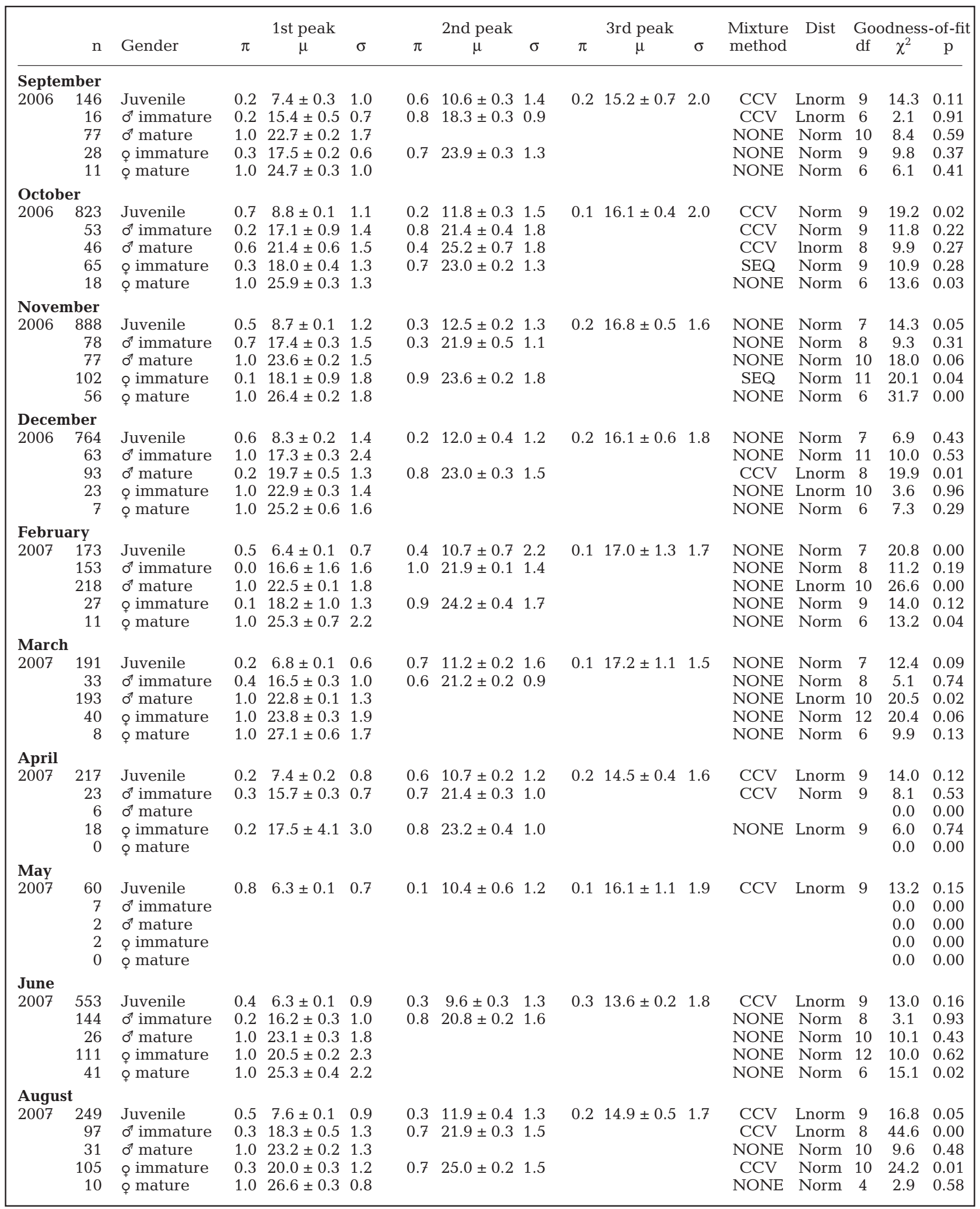


dance of mature females was low throughout the year. The highest number of mature females was found in November and June. The development of the females was followed through oostegite classification on a total of 304 females (Table 3). This showed that the oostegite classes 'tiny' and 'small' fall into the first cohort of immature females, whereas the class 'intermediate' belongs to the second cohort of immature females. Few females were recorded in the 'long' oostegite class, and their lengths were similar to those in the 'intermediate' class. A $t$-test confirmed that the 'intermediate' class had different mean lengths than mature females $(t=10.0, \mathrm{df}=168.5, \mathrm{p}<0.001)$, indicating that they belonged to different cohorts.

\section{Time of reproduction and recruitment}

Only 1 brood was observed, and females with eggs were recorded in February, March, and June. In February and March, all eggs were still undeveloped (round, with the outer membrane close to the yolk), but, in June, the eggs had developed and in some eggs pereopods were visible. In August, no females were observed carrying eggs or juveniles, suggesting that the release of juveniles takes place in July to August. The smallest observed females carrying eggs were $22 \mathrm{~mm}$, while the largest were $29 \mathrm{~mm}$. The average number of eggs per female was 11.4 , ranging from 7 to 17. The mean $( \pm \mathrm{SD})$ diameter of the eggs was $1.68 \pm$ $0.11 \mathrm{~mm}$.

\section{DISCUSSION}

The biology of polar marine organisms is affected by the seasonality of the environment (Arndt \& Swadling 2006, Peck et al. 2006) and the solar cycle drives the seasonality in primary production. Despite the effect of inter-annual variation in sea-surface temperature, vertical stratification, and presence or absence of sea-ice on its timing, length, and intensity, the algal spring bloom predominates (Michel et al. 2006, Wassmann et

Table 3. Onisimus caricus. Lengths of females (mm), mean \pm SD (SE), in oostegite development classes. $-95 \%$ CL and + 95\% CL: lower and upper $95 \%$ confidence limits, respectively

\begin{tabular}{|lrrrrr|}
\hline Oostegite class & $\mathrm{n}$ & & Length- & $\begin{array}{c}-95 \% \\
\mathrm{CL}\end{array}$ & $\begin{array}{c}+95 \% \\
\mathrm{CL}\end{array}$ \\
\hline Tiny & & & & & \\
Small & 38 & $19.1 \pm 1.7$ & $(0.3)$ & 18.5 & 19.7 \\
Intermediate & 77 & $20.9 \pm 1.5$ & $(0.3)$ & 20.3 & 21.5 \\
Long & 4 & $24.0 \pm 1.3$ & $(0.2)$ & 23.7 & 24.3 \\
Adult & 163 & $26.0 \pm 1.5$ & $(0.7)$ & 23.5 & 26.3 \\
& & & & & \\
\hline
\end{tabular}

al. 2006). This pronounced seasonality in primary production also governs the life cycles of the consumers favoring a single brood per year, well timed to the high productive season (Węsławski \& Legeżyńska 2002, Arndt \& Swadling 2006). Our data on Onisimus caricus showed 1 synchronized brood per year. Thus, the cohorts identified in the length-frequency distribution can be regarded as year classes, and interpretation of the life cycle can therefore be done based on these.

Reproduction in polar crustaceans usually takes place during winter (Węsławski \& Legeżyńska 2002). In amphipods, fertilization of the eggs takes place externally in the brood pouch, where they thereafter develop and are released as juveniles (Schram 1986). In our study, females with eggs were first observed in February, suggesting reproduction takes place then. However, it is possible that they already carry eggs in January, as we lack observations from this month. The high abundances of mature males in the catch in February and March also indicate that mating takes place at this time, since lysianassoid males swarm and increase their movement during the mating period (Conlan 1991), and therefore also are more susceptible to being trapped.

The eggs of Onisimus caricus are among the largest observed among lysianassoid amphipods. Only Alicella gigantea and Eurythenes gryllus have been reported to have larger eggs (Sainte-Marie et al. 1990), but these are species of a considerably larger size. The brood size is small, but of comparable size to many other lysianassoids (Sainte-Marie et al. 1990). However, the lysianassoid species in the genus Anonyx, which are also very common in Adventfjorden, seem to have a different strategy when it comes to reproduction. In the review by Sainte-Marie (1991) Anonyx spp. are reported to have very big broods, up to 630 embryos in A. nugax. Our own observations of Anonyx spp. also verify this. Thus, these species, probably competing for the same resources, have different reproductive strategies, which, together with depth distributions and feeding habits, apparently make it possible for them to co-occur in the fjord.

The incubation period of eggs in amphipods depends on egg size and temperature (Steele \& Steele 1973, 1975). Our observations show that Onisimus caricus incubates the eggs for 150 to $180 \mathrm{~d}$ before the juveniles hatch and are released from the brood pouch. The incubation time is relatively short compared to the size of the eggs and prevailing temperature $\left(-1.2\right.$ to $\left.0.9^{\circ} \mathrm{C}\right)$, but of comparable length to other polar amphipods (Bregazzi 1972, Sagar 1980, Poltermann et al. 2000).

Glacial bays have some special features in terms of their physical conditions. Hydrographic conditions vary over the year from a maritime environment in the winter, often covered by sea-ice, to a low-salinity surface 

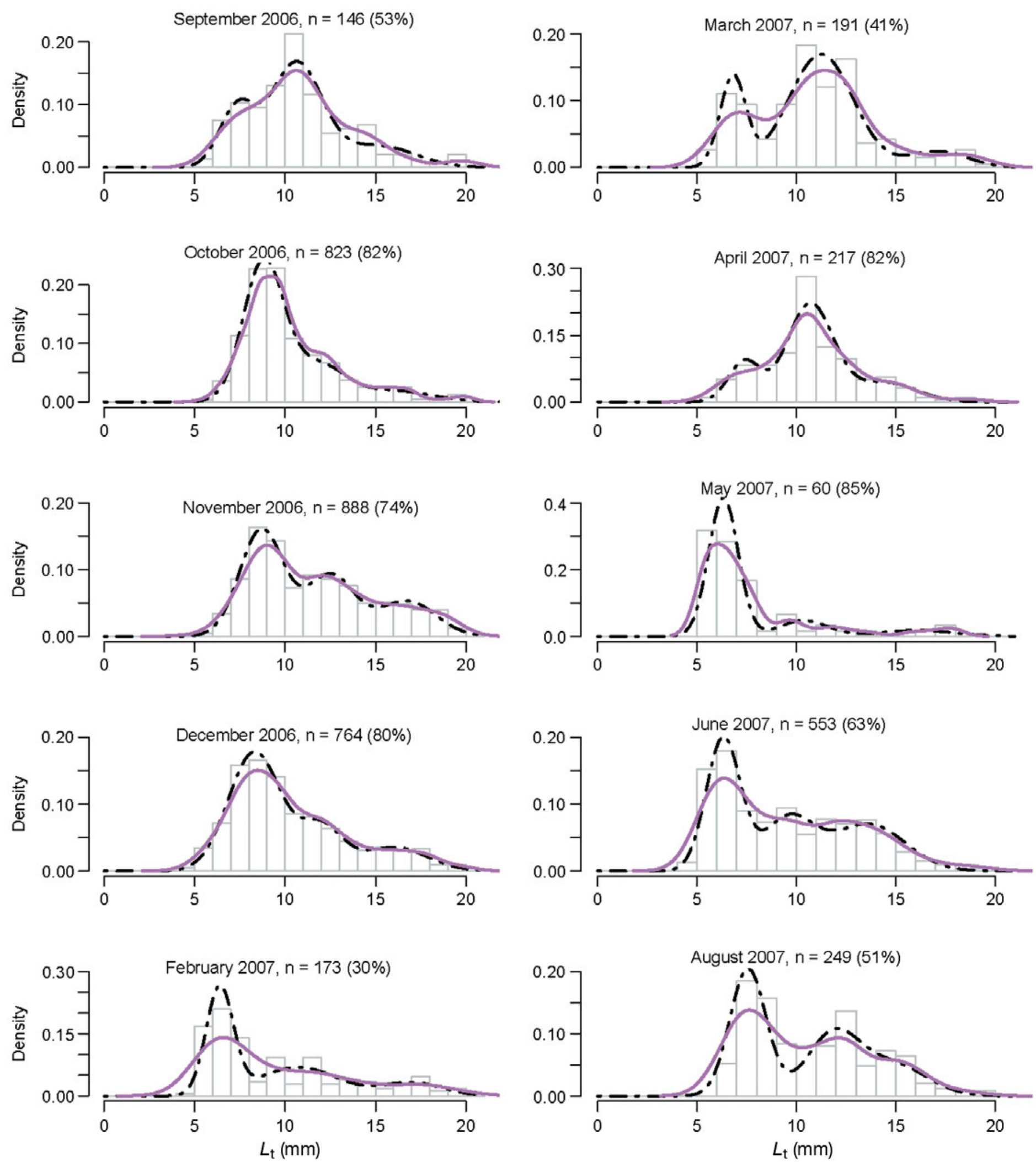

Fig. 3. Onisimus caricus. Total length $\left(L_{t}\right)$-relative frequency distribution of juveniles in different months. Histogram: observations; purple: kernel density distribution; dot-dash: modeled cohort structure; \%: proportion of juveniles in the subsample. Density refers to proportion of the subsample, total area under the curves $=1$. Note different on $y$-axis scales 

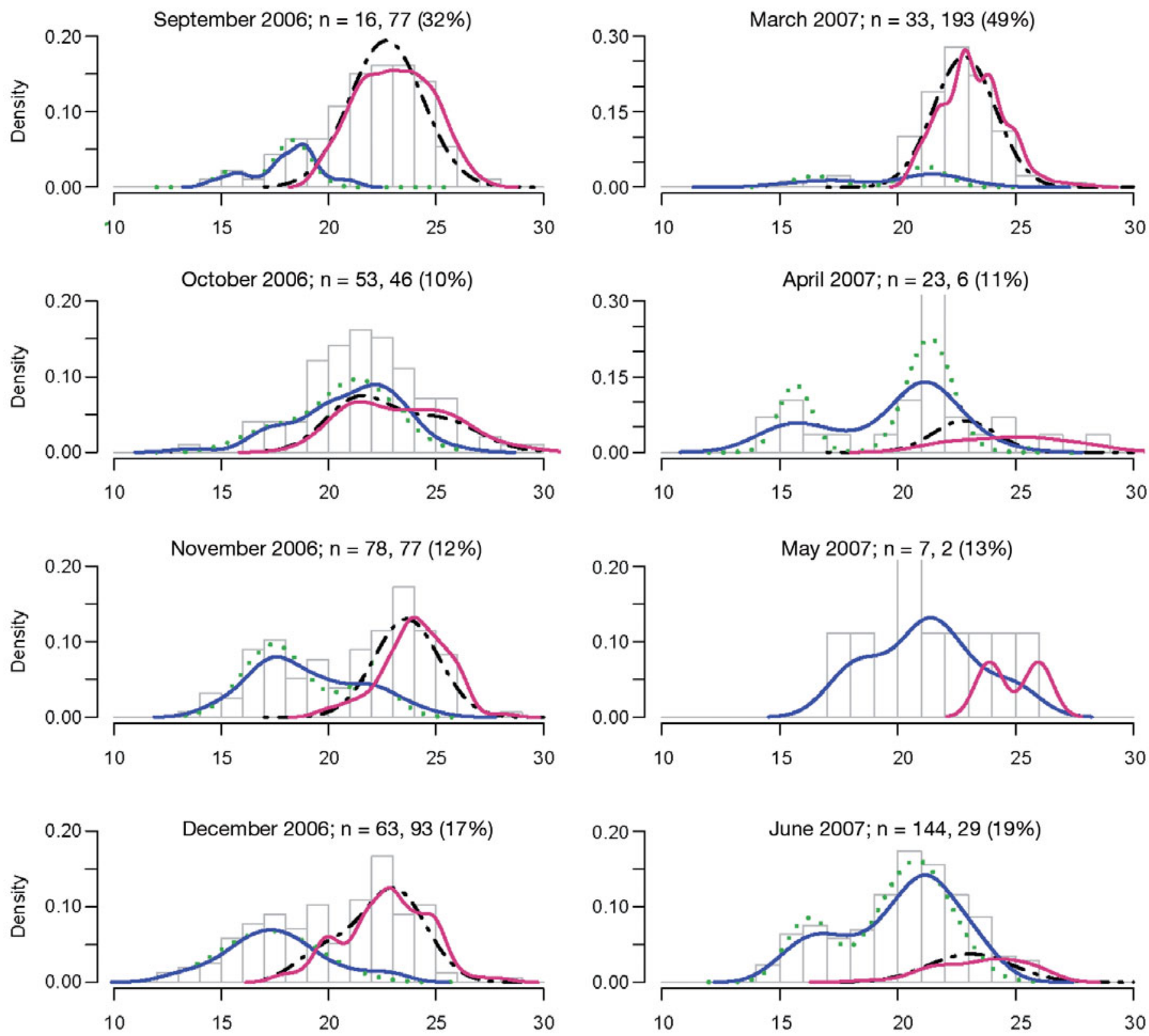

February $2007 ; n=153,218(64 \%)$

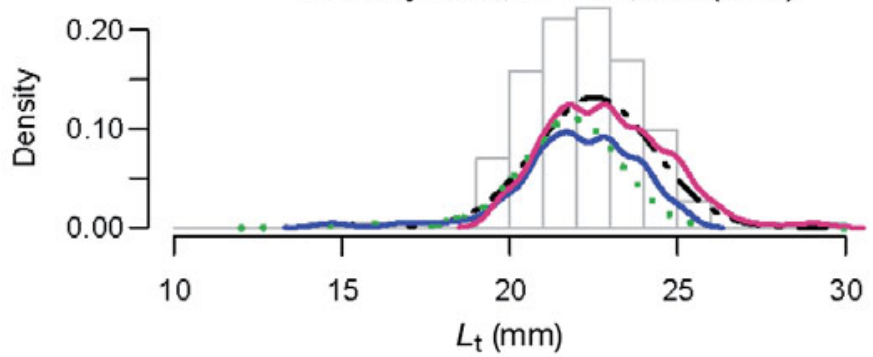

August 2007; $n=97,31(26 \%)$

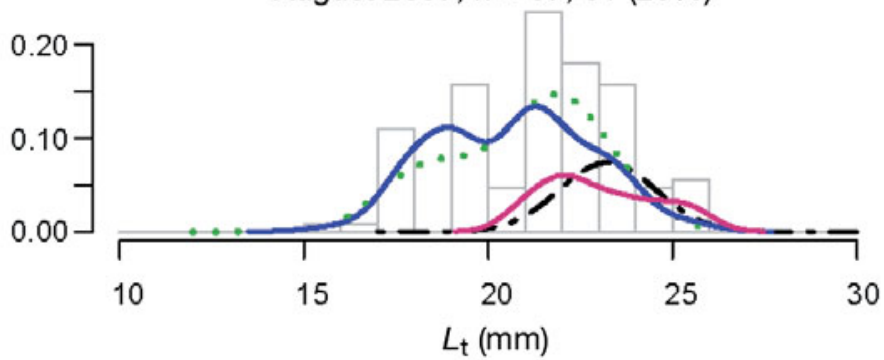

Fig. 4. Onisimus caricus. Total length $\left(L_{t}\right)$-relative frequency distribution of males in different months. Histogram: observations; blue and red: kernel density distribution (immature and mature, respectively); green and dot-dash: modeled cohort structure (immature and mature, respectively); n: number of measured specimens (immature, mature); (\%) proportion of males in the subsample. Density refers to proportion of the subsample, total area under the curves $=1$. Note different on $y$-axis scales 

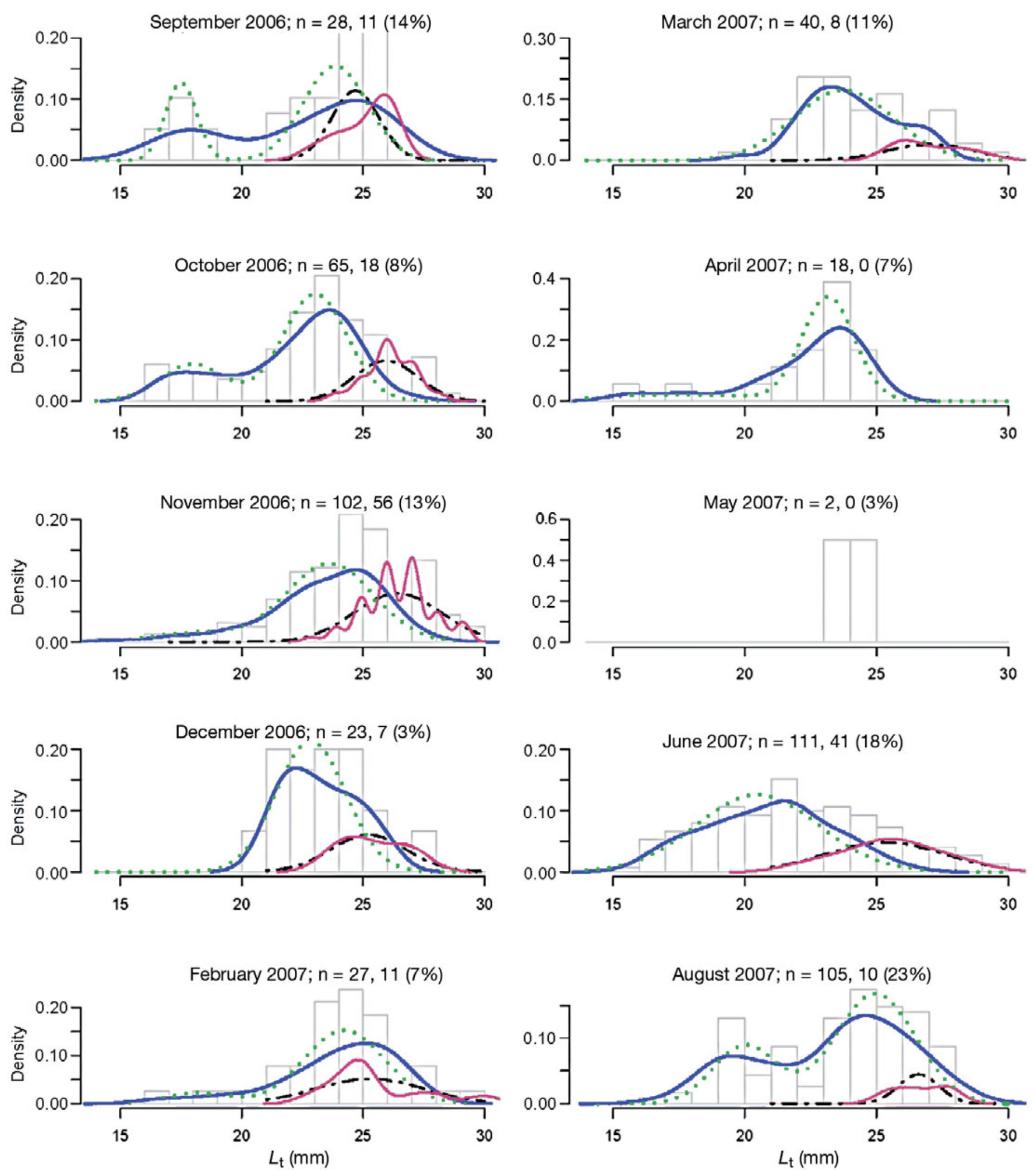

Fig. 5. Onisimus caricus. Total length $\left(L_{t}\right)$-relative frequency distribution of females in different months. Histogram: observations; blue and red: kernel density distribution (immature and mature, respectively); green and black: modeled cohort structure (immature and mature, respectively); n: number of measured specimens (immature, mature); (\%) proportion of females in the subsample. Density refers to proportion of the subsample, total area under the curves $=1$. Note different $y$-axis scales 
layer in the summer as a consequence of freshwater run-off from land during the short summer melting period. The surface layer in the summer is several meters thick. In Adventfjorden the freshwater inflow from glacial rivers starts in late May, reaches its maximum in July, and ends in September (Węsławski et al. 1999). Marine zooplankton, such as calanoid copepods and hyperiid amphipods, cannot tolerate the rapid change in salinity (from $\sim 34$ to $\sim 10$ PSU), and such events result in osmotic shock and mass mortality (Zajączkowski \& Legeżyńska 2001, Eiane \& Daase 2002). Dead zooplankton serves as an important input of organic material to the benthic scavengers, and Onisimus caricus is one of the major beneficiaries this (Zajączkowski \& Legeżyńska 2001, Legeżyńska 2008). Arndt \& Swadling (2006) concluded that the release of the brood in polar crustaceans should be timed to the most productive time of the year. Generally, the most productive time is the spring bloom of phytoplankton or ice algae, and many organisms, including some scavenging amphipods, have timed their recruitment to coincide with these 2 major events (Niehoff et al. 2002, Ringuette et al. 2002, Węsławski \& Legeżyńska 2002, Arndt \& Beuchel 2006, Leu et al. 2006). For O. caricus, which is a scavenging carnivore, the algal bloom may not be as important as a primary source of food. Rather, the input of organic material from dead zooplankton sinking to the bottom during the melting period might be the most favorable moment for this species to release its brood. Therefore, we hypothesize that the release of juveniles in July is correlated with the high abundance of suitable food, such as dead zooplankton.

Comparing the most developed embryos with the smallest juveniles caught in this study suggests that the newly released juveniles are not caught by baited traps. In August, when there should have been newly released juveniles present, the lengths of the smallest juveniles were approximately twice the perimeter of the eggs in June. The smallest juveniles recorded by Węsławski \& Legeżyńska (2002) were caught in July and were $3 \mathrm{~mm}$ long. There are no data on the feeding preferences of newly released Onisimus caricus juveniles. Legeżyńska (2008) reports that the length class of from 6.5 to $10 \mathrm{~mm}$ mainly feed on crustaceans, but compared to the diet of larger specimens they consume more amorphous organic matter and detritus, while carrion is less frequent. This could indicate that the newly released juveniles are less attracted to bait than are larger specimens. In addition, small individuals are probably less motile and therefore rely on more accessible food resources, such as dead zooplankton and detritus. In our study, the smallest juveniles were observed in February, suggesting that this is the first time the juveniles from last summer's hatching are attracted to the bait in the traps.

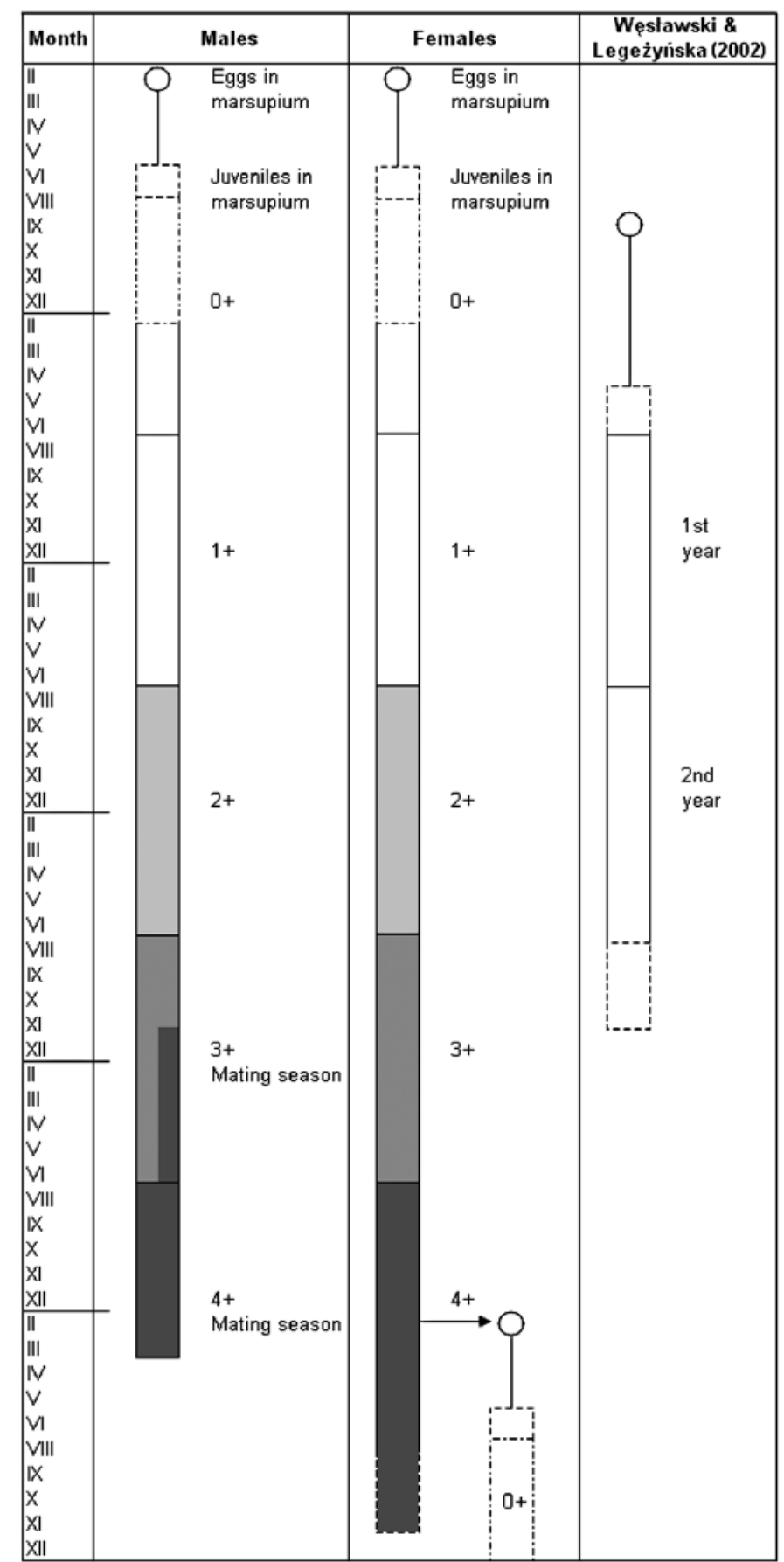

Fig. 6. Onisimus caricus. Predicted life cycle for males and females. White boxes: juveniles; intermediate coloring (2 shades of grey): immature individuals; darkest boxes: mature specimens. 0+ to $4+$ : year classes. The right column is for comparison of our interpretation of the life cycle data with that presented in Węsławski \& Legeżyńska (2002)

By interpreting the length-frequency distribution and the cohort structure, the following life cycle was defined (Fig. 6). Juveniles are released from the brood pouch in July to August and develop as juveniles for 
2 yr. In their third year, they develop into immature adults and develop their sexual characters. The development into immature adults does not seem to be synchronized, and therefore cohorts will consist of a mixture of immature adults and juveniles. The males start maturing approximately $1 \mathrm{yr}$ after they develop into immature adults, and some males reach maturity before the mating season in their fourth year, whereas others mature in their fifth year. Mature males are present throughout the year, suggesting that the males that mature in their fourth year survive until the mating season in the fifth year, thus getting 2 chances to mate. Males die after the mating season in their fifth year, and thus have a lifespan of $4.5 \mathrm{yr}$. The females live for $2 \mathrm{yr}$ as immature individuals, and reach maturity in their fifth autumn, as shown by the development of oostegites. Females reproduce only once, and, after mating in February, they carry the brood until the eggs hatch and are released in July to August at which time the females die after a 5 yr lifespan.

Based on 84 Onisimus caricus collected on a single sampling date, Węsławski \& Legeżyńska (2002) proposed a 2 yr lifespan. This was based on only lengthfrequency data, not taking into account the different development stages. Our data, consisting of $>6000$ ind. from 10 sampling dates over $1 \mathrm{yr}$, indicate a $5 \mathrm{yr}$ lifespan. In the samples, all cohorts, except the youngest juveniles, could be identified. Sampling with baited traps probably affects the estimates of relative abundance of the different cohorts. The smallest juveniles and ovigerous females are most likely underrepresented, due to different food preferences and a retraction of the gut in ovigerous females (Sainte-Marie et al. 1990, Legeżyńska 2008); and males are overrepresented during the mating season (Conlan 1991). Nevertheless, it is possible to detect the different cohorts and thereby to study the life cycle of the species. The length-frequency distribution presented in Węsławski \& Legeżyńska (2002) is very similar to our observations, but the interpretation of the results differs, mainly because our data are gender specific.

Growth is slow and almost linear during development and flattens out when the individual matures (Fig. 7, Table 4). Females seem to have a slightly faster growth rate than males in the first $3 \mathrm{yr}$, and therefore reach a larger size. Compared to its sympagic congeneric species Onisimus nanseni and O. glacialis (Vader et al. 2005), $O$. caricus has an intermediate growth rate, growing more slowly than $O$. nanseni but faster than O. glacialis (Arndt \& Beuchel 2006). But due to its longer lifespan O. caricus reaches a larger size than $O$. nanseni.

Growth is not continuous in amphipods, since growth is connected to molting, and

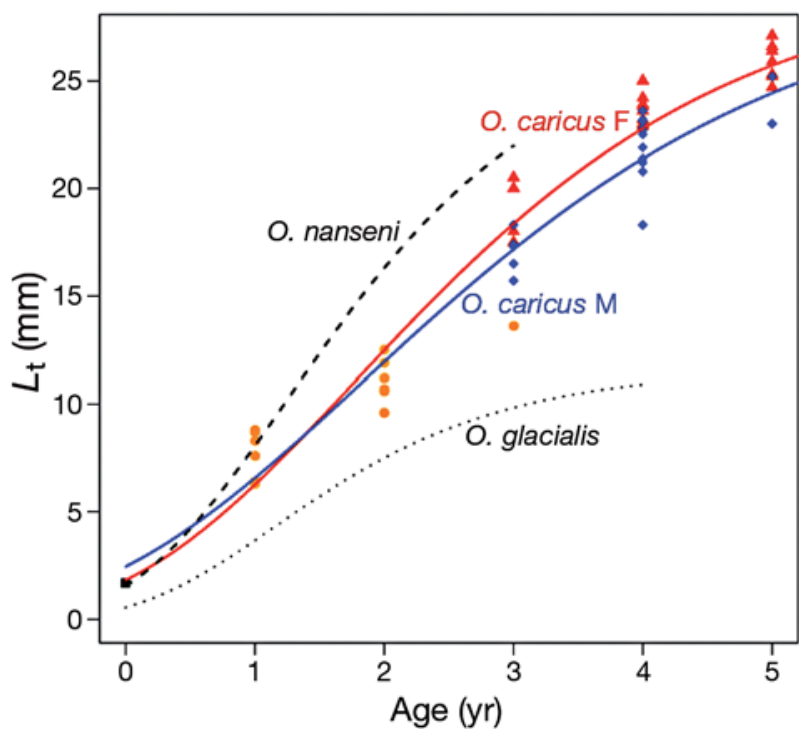

Fig. 7. Onisimus caricus, O. nanseni and O. glacialis. Gompertz growth curve for $O$. caricus (blue and red lines for males and females, respectively), O. nanseni (black dashed line; Arndt \& Beuchel 2006) and O. glacialis (black dotted line; Arndt \& Beuchel 2006). Black square: mean size of eggs; orange dots: mean total length $\left(L_{t}\right)$ for juvenile cohorts; blue diamonds: mean length for male cohorts; red triangles: mean length for female cohorts

it has been suggested that the number of molts rather than the size determines when amphipods mature (Highsmith \& Coyle 1991), which explains the differences in size among mature individuals. Growth slows down while amphipods are maturing, since females probably invest energy in developing gonads instead of growth and after maturation they do not molt while carrying the brood.

Low temperature is the context for slow development and growth in polar invertebrates in general, leading to late maturation and a long lifespan (Peck et al. 2006). These characters, together with small brood size and semelparity, are typical for the adverseselective ( $A$-selective) life-history pattern defined by Greenslade (1983). This life-history pattern differs from the more commonly used r- and $K$-selection with respect to the organisms' habitat characteristics, such as poor productivity (adverse) and rare disturbance

Table 4. Onisimus caricus, O. nanseni and O. glacialis. Gompertz growth curve parameters. See 'Materials and methods' for explanations of the parameters

\begin{tabular}{|lccccl|}
\hline Species & Gender & $L_{\mathrm{t} \lim }$ & $k$ & $b$ & Source \\
\hline O. caricus & Juveniles $+\sigma^{7}$ & 30.00 & 2.79 & 0.56 & Present study \\
O. caricus & Juveniles $+o^{+}$ & 30.00 & 2.50 & 0.61 & Present study \\
O. nanseni & All & 27.45 & 2.87 & 0.85 & Arndt \& Beuchel (2006) \\
O. glacialis & Juveniles $+\sigma^{7}$ & 11.64 & 3.02 & 0.96 & Arndt \& Beuchel (2006) \\
\hline
\end{tabular}


(Greenslade 1983). Generalized, these conditions control organisms in deep seas and at high latitudes, and the $A$-selective life-history pattern is common among Arctic gammaridean amphipods (Greenslade 1983, Sainte-Marie 1991, Węsławski \& Legeżyńska 2002). The life-history pattern of Onisimus caricus follows the typical $A$-selection pattern, with a long lifespan, slow development, small brood size, and large eggs. The Isfjorden complex, including Adventfjorden, is exposed to pronounced inter-annual variations in environmental conditions that influence the benthic community and species composition (Berge et al. 2005). A change towards a warmer climate is likely to further enhance this variability (Nilsen et al. 2008), mainly due to increased variability in the influx of Atlantic water, and might thus further increase the physical forcing on benthic community structure (e.g. Renaud et al. 2007, Berge et al. in press). Thus, $A$-selective organisms, such as $O$. caricus, may experience higher disturbance, with a negative effect on their productivity, leading to a reduction in population sizes.

In conclusion, Onisimus caricus seems to have a $5 \mathrm{yr}$ life cycle in Adventfjorden. It is essentially semelparous, although some males may be iteroparous. The large egg size, low fecundity, long lifespan, and slow growth rate suggest that $O$. caricus is a typical $A$ selected species. The species benefits from the input of zooplankton that die due to osmotic shock in glacial bays in the melting period, the time when $O$. caricus releases its brood.

Acknowledgements. We thank Katrine Berg-Hansen, Laurel McFadden and Dr. Marek Zajączkowski for their help during fieldwork and in the laboratory. Thanks also to Dr. Heikki Hämäläinen, Prof. Nigel Yoccoz and Prof. Peter MacDonald for discussions regarding data analyses and statistics.

\section{LITERATURE CITED}

Arndt CE, Beuchel F (2006) Life history and population dynamics of the Arctic sympagic amphipods Onisimus nanseni Sars and O. glacialis Sars (Gammaridea: Lysianassidae). Polar Biol 29:239-248

Arndt CE, Swadling KM (2006) Crustacea in Arctic and Antarctic sea ice: distribution, diet and life history strategies. Adv Mar Biol 51:197-315

Arndt CE, Gulliksen B, Lønne OJ, Berge J (in press) Sea ice fauna. In: Sakshaug E, Johnsen G, Kovacs K (eds) Ecosystem Barents Sea, Chap 13. Academic Press, Tapir

Berge J, Johnsen G, Nilsen F, Gulliksen B, Slagstad D (2005) Ocean temperature oscillations enable reappearance of blue mussels Mytilus edulis in Svalbard after a 1000 year absence. Mar Ecol Prog Ser 303:167-175

Berge J, Renaud PE, Eiane K, Gulliksen B, Cottier FR, Varpe $\varnothing$, Brattegard $\mathrm{T}$ (in press) Changes in the decapod fauna of an Arctic fjord during the last hundred years. Polar Biol

Beuchel F, Lønne OJ (2002) Population dynamics of the sympagic amphipods Gammarus wilkitzkii and Apherusa glacialis in sea ice north of Svalbard. Polar Biol 25: 241-250

Boudrias MA, Carey AG Jr (1988) Life history patterns of Pseudalibrotus litoralis (Crustacea: Amphipoda) on the inner continental shelf, SW Beaufort Sea. Mar Ecol Prog Ser 49:249-257

Bregazzi PK (1972) Life cycles and seasonal movements of Cheirimedon femoratus (Pfeffer) and Tryphosella kergueleni (Miers) (Crustacea: Amphipoda). Br Antarct Surv Bull 30:1-34

> Conlan KE (1991) Precopulatory mating behaviour and sexual dimorphism in the amphipod Crustacea. Hydrobiologia 223:255-282

> De Broyer C, Nyssen F, Dauby P (2004) The crustacean scavenger guild in Antarctic shelf, bathyal and abyssal communities. Deep Sea Res II 51:1733-1752

Dempster AP, Laird NM, Rubin DB (1977) Maximum likelihood from incomplete data via the EM algorithm. J R Statist Soc B39:1-38

Du J (2002) Combined algorithms for fitting finite mixture distributions. MS thesis, McMaster University, Hamilton, Ontario

Eiane K, Daase M (2002) Observations of mass mortality of Themisto libellula (Amphipoda, Hyperidae). Polar Biol 25: 396-398

Greenslade PJM (1983) Adversity selection and the habitat templet. Am Nat 122:352-365

Highsmith RC, Coyle KO (1991) Amphipod life histories: community structure, impact of temperature on decoupled growth and maturation rates, productivity, and $\mathrm{P}: \mathrm{B}$ ratios. Am Zool 31:861-873

> Ingram GL, Hessler RR (1983) Distribution and behavior of scavenging amphipods from the central North Pacific. Deep-Sea Res 30:683-706

> Legeżyńska J (2008) Food resource partitioning among Arctic sublittoral lysianassoid amphipods in summer. Polar Biol 31:663-670

> Legeżyńska J, Węsławski JM, Presler P (2000) Benthic scavengers collected by baited traps in the high Arctic. Polar Biol 23:539-544

> Leu E, Falk-Petersen S, Kwasniewski S, Wulff A, Edvardsen K, Hessen DO (2006) Fatty acid dynamics during the spring bloom in a High Arctic fjord: importance of abiotic factors versus community changes. Can J Fish Aquat Sci 63:2760-2779

> Lønne OJ, Gabrielsen GW (1992) Summer diet of seabirds feeding in sea-ice-covered waters near Svalbard. Polar Biol 12:685-692

Lønne OJ, Gulliksen B (1989) Size, age and diet of polar cod, Boreogadus saida (Lepechin, 1773), in ice covered waters. Polar Biol 9:187-191

MacDonald P, Green P (1988) Users guide to Program MIX: an interactive program for fitting mixtures of distribution. Ichthus Data Systems, Hamilton, Ontario

MacDonald PDM, Pitcher TJ (1979) Age-groups from size-frequency data: a versatile and efficient method of analyzing distribution mixtures. J Fish Res Board Can 36:987-1001

Michel C, Ingram RG, Harris LR (2006) Variability in oceanographic and ecological processes in the Canadian Arctic Archipelago. Prog Oceanogr 71:379-401

> Niehoff B, Madsen SD, Hansen BW, Nielsen TG (2002) Reproductive cycles of three dominant Calanus species in Disko Bay, West Greenland. Mar Biol 140:567-576

> Nilsen F, Cottier F, Skogseth R, Mattsson S (2008) Fjord-shelf exchanges controlled by ice and brine production: the interannual variation of Atlantic water in Isfjorden, Svalbard. Cont Shelf Res 28:1838-1853 
Palerud R, Gulliksen B, Brattegard T, Sneli JA, Vader W (2004) The marine macro-organisms in Svalbard waters. In: Prestrud P, Strøm H, Goldman HV (eds) A catalogue of the terrestrial and marine animals of Svalbard, Vol 201. Skrifter, Norsk Polarinstitutt, Tromsø, p 5-56

Peck LS, Convey P, Barnes DKA (2006) Environmental constraints on life histories in Antarctic ecosystems: tempos, timings and predictability. Biol Rev Camb Philos Soc 81: 75-109

Poltermann M, Hop H, Falk-Petersen S (2000) Life under Arctic sea ice-reproduction strategies of two sympagic (iceassociated) amphipod species, Gammarus wilkitzkii and Apherusa glacialis. Mar Biol 136:913-920

Premke K (2006) Aggregations of Arctic deep-sea scavenging amphipods at large food falls. Ber Polarforsch 531: $1-134$

Renaud PE, Włodarska-Kowalczuk, Trannum H, Holte B, Węsławski JM, Cochrane S, Dahle S, Gulliksen B (2007) Multidecadal stability of benthic community structure in a high-Arctic glacial fjord (van Mijenfjord, Spitsbergen). Polar Biol 30:295-305

Ringuette M, Fortier L, Fortier M, Runge JA and others (2002) Advanced recruitment and accelerated population development in Arctic calanoid copepods of the North water. Deep Sea Res II 49:5081-5099

Sagar PM (1980) Life cycle and growth of the Antarctic gammarid amphipod Paramoera walkeri (Stebbing, 1906). J R Soc NZ 10:259-270

Sainte-Marie B (1991) A review of the reproductive bionomics of aquatic gammaridean amphipods: variation of life history traits with latitude, depth, salinity and superfamily. Hydrobiologia 223:189-227

Sainte-Marie B, Lamarche G, Gagnon JM (1990) Reproductive binomics of some shallow-water lysianassoids in the Saint Lawrence Estuary, with a review on the fecundity of the Lysianassoidea (Crustacea, Amphipoda). Can J Zool 68:1639-1644

Schram FR (1986) Crustacea. Oxford University Press, New York

Slattery PN, Oliver JS (1986) Scavenging and other feeding

Editorial responsibility: Judith Grassle,

New Brunswick, New Jersey, USA habits of lysianassoid amphipods (Orchomene spp.) from McMurdo Sound, Antarctica. Polar Biol 6:171-177

Steele DH, Steele VJ (1973) The biology of Gammarus (Crustacea, Amphipoda) in the northwestern Atlantic. VII. The duration of embryonic development in five species at various temperatures. Can J Zool 51:995-999

Steele DH, Steele VJ (1975) Egg size and duration of embryonic development in Crustacea. Int Rev Gesamten Hydrobiol 60:711-715

Steen H, Vogedes D, Broms F, Falk-Petersen S, Berge J (2007) Little auks (Alle alle) breeding in a high Arctic fjord system: bimodal foraging strategies as a response to poor food quality? Polar Res 26:118-125

- Vader W, Johnsen JR, Berge J (2005) Studies on the genus Onisimus Boeck, 1871 (Crustacea, Amphipoda, Lysianassoidea, Uristidae). I. The brevicaudatus and sextonae species groups. Org Divers Evol 5:161-164

Wassmann P, Reigstad M, Haug T, Rudels B and others (2006) Food webs and carbon flux in the Barents Sea. Prog Oceanogr 71:232-287

Węsławski JM, Legeżyńska J (2002) Life cycles of some Arctic amphipods. Pol Polar Res 23:253-264

Węsławski JM, Ryg M, Smith TG, Oritsland NA (1994) Diet of ringed seal (Phoca hispida) in a fjord of west Svalbard. Arctic 47:109-114

Węsławski JM, Szymelfenig M, Zajączkowski M, Keck A (1999) Influence of salinity and suspended matter on benthos of an Arctic tidal flat. ICES J Mar Sci 56:194-202

Węsławski JM, Opaliński KW, Legeżyńska J (2000) Life cycle and production of Onisimus litoralis (Crustacea, Amphipoda): the key species in the Arctic soft sediment littoral. Pol Arch Hydrobiol 47:585-596

Wildish DJ (1982) Evolutionary ecology of reproduction in gammaridean Amphipoda. Int J Invertebr Reprod 5:1-19

Zajączkowski M (2008) Sediment supply and fluxes in glacial and outwash fjords, Kongsfjorden and Adventfjorden, Svalbard. Pol Polar Res 29:59-72

Zajączkowski M, Legeżyńska J (2001) Estimation of zooplankton mortality caused by an Arctic glacier outflow. Oceanologia 43:341-351

Submitted: October 16, 2008; Accepted: January 9, 2009 Proofs received from author(s): February 17, 2009 